Journal of Teacher Education for Sustainability, vol. 23, no. 1, pp. 84-98, 2021

\title{
Student Teachers' Change Agency in Education for Sustainable Development
}

\author{
Teija Koskela \\ University of Turku, Rauma, Finland \\ Sirpa Kärkkäinen \\ University of Eastern Finland, Joensuu, Finland
}

\begin{abstract}
Previous research shows that teachers are key players in supporting agency in the face of the biggest global challenges of our time, such as climate change and pollution, as teachers educate societies' future decision-makers. The aim of this study was to analyze student teachers' perceptions of change agency and sustainable development. In this qualitative case study, the writings of student teachers $(n=116)$ were studied in the context of sustainable development education. The data were analyzed using content analysis. The findings of the research confirmed previous studies showing that student teachers' perceptions of sustainable development were quite narrow. The results indicated that the student teachers wrote mainly about social dimensions of sustainable development; few of them considered economic or environmental dimensions of sustainable development. The results provided new information about the current state of student teachers' perceptions of change agency in the teacher education context. Teacher education should focus more on a holistic view of sustainable development aspects. These findings might be useful in implementing teacher education curricula.
\end{abstract}

Key words: change agency, education for sustainable development (ESD), teacher education, AGENDA 2030

\section{Introduction}

Teachers are described globally as key persons to support agency against threats such as climate change and pollution (UNESCO, 2016). Teacher education has a remarkable role in enhancing teachers' ability to promote education for sustainable development (ESD) (UNESCO, 2018). In society, there is a need to encourage students, as future citizens, to take individual and participatory action and contribute more effectively to sustainable development (Vesterinen, Tolppanen, \& Aksela, 2016). The integration of ESD in schools requires the commitment of teachers; there is therefore a need to pursue the inclusion of ESD in teacher education in a more systematic manner (Esa, 2010; Waltner, Riesß, \& Block, 2018). Research on student teachers as change agents is relatively 
rare, although teachers' views are factors affecting their planning and teaching sustainability (Quinn, Castéra, \& Clément, 2016). The aim of this study is to analyze student teachers' orientation and intentions regarding change agency and sustainable development.

\section{Education for Sustainable Development}

Sustainability is a rather multidimensional approach to several phenomena. In educational research, it can be seen as a three-dimensional model consisting of the environment, the society and the economy (Tolppanen \& Aksela, 2018; Maurer \& Bogner, 2019). According to Quinn, Maclean and Park (2009), there are three principal dimensions in sustainability: an environmental dimension, an economic dimension and a social one. Different dimensions are complexly interrelated. In teaching and learning sustainable development, the environmental dimension includes all living things, resources and lifesupporting systems. The economic dimension consists of jobs and income and its goal is appropriate development. The social dimension involves people living together and highlights peace, equality and human rights. Previous research (Nousheen et al., 2020) highlighted that there was a need for education on the economic dimension of sustainable development in particular. It is important that student teachers understand the relevance of ESD and sustainable development to their lives. Prior studies also highlight local and global perspectives on sustainability (Nousheen et al., 2020).

Sustainable development is seen as a large and complex phenomenon. Sustainable development goals identify several problems and give names to them. For example, in AGENDA 2030 (United Nations [UN], 2015), all 17 goals are internationally discussed and recognized on a global level, such as politics and world trade. Goals are partly intertwined and explicit consequences are different in local contexts. They consist, for example, of a political dimension as well as a health dimension. The political dimension has to do with politics and decision-making as a goal of democracy, while health is centrally positioned within the AGENDA 2030 (UN, 2015; WHO, 2016; Bennett et al., 2020).

Sustainability is strongly connected to individual action and consumption (Bengtsson et al., 2018). It is part of every person's life consciously or unconsciously. The global level affects the individual level through complex processes and networks, which pose a challenge in research practices (see Corcoran, Walker, \& Wals, 2004). This makes sustainability a very contradictory phenomenon: it is linked to everything we do, and at the same time there are multiple complex connections, so supporting one dimension can cause harm to another dimension. As political, personal, global and local phenomena, real world sustainability problems seem to be sensitive and emotional on the individual level (Pihkala, 2018).

ESD is connected and compared to several educational approaches (Murillo-Vargas, Gonzales-Campo, \& Brath, 2020), such as environmental (Esa, 2010; Wanchana, Inprom, Rawang, \& Ayudhya, 2020) and climate education (Anderson, 2012), inclusive education and social justice (Torbjörnsson \& Molin, 2015; Sunthonkanokpong \& Murphy, 2019) and citizenship education (Vesterinen et al., 2016; Jimenez, Lerch, \& Bromley, 2017). As a theoretical background to our research questions, we further exemplify previous research results concerning the knowledge of sustainability in education. 


\section{Education for Sustainability in Pre-service Teacher Education}

Teacher training has been identified as a crucial element of making education systems more responsive to sustainability challenges (Rickinson, 2001; UNESCO, 2016; Brandisauskiene, Cesnaviciene, Miciuliene, \& Kaminskiene, 2020). However, there are many challenges in implementing ESD in teacher education. There is a lot of information about ESD and students' understanding of ESD is relative, multidimensional and fragile (Maurer \& Bogner, 2019). Different backgrounds, definitions and understandings are difficult to combine without misunderstandings.

Previous research has shown that ESD in teacher training has positive effects on student teachers' awareness (e.g., Nousheen et al., 2020). Tomas et al. (2017) conducted a study on student teachers' attitudes to education for sustainability after studying an ESD course. The findings reflected that the teachers' attitudes to social and environmental problems changed in a positive manner after the course, and they developed knowledge, attitudes and skills for teaching ESD in schools. Similarly, the research of Laurie et al. (2016) indicated that incorporating ESD in preparatory teacher training programs contributed to quality education in different ways at the primary and secondary level of education. The research also suggested that the teaching-learning process would transform when the contents of teacher education included ESD. Consequently, the pedagogies promote values, perspectives and skills in classrooms which are essential for nurturing societies. The results of the study of Anderson (2012) also showed that an ESD course positively affects the perceptions of prospective teachers regarding how to teach issues related to ESD to students in classrooms. The shift of ESD to communities through teaching is essential. Teachers can promote a culture of sustainability and a healthy environment among different communities through training individuals based on values such as integrity, peace, resolving conflicts, tolerance and respect for other cultures (Chinedu et al., 2018). According to Mckeown (2014), student teachers' development should focus on the effective implementation of ESD and student development.

\section{Agency}

Significant changes are needed in the field of education in order to promote change in society. Teachers need the skills to bring new approaches, methods and contents into schools to enhance sustainable development in their work. The concept of agency provides a possibility to study the interplay between the aims and actions of the individual and his/her physical and social environment.

Human agency is connected to aims or values. It is described as an actor or individual acting intentionally to promote certain purposes, which requires capacity and power, and awaiting the consequences of the action (Giddens, 1984). More specifically, agency is "temporally constructed engagement by actors of different structural elements ... which, through the interplay of habit, imagination and judgement both reproduces and transforms those structures in interactive response to the problems posed by changing historical situations” (Emirbayer \& Mische, 1998, p. 970). This definition highlights iterative, projective and practical-evaluative elements of engagement and how they are selectively recognized, located and implemented in certain circumstances (Emirbayer \& Mische, 1998). 
Agency is connected to person-practice dynamics (Edwards, 2017) and professional agency locates professional subjects in certain sociocultural conditions where individuals or communities exert influence (Eteläpelto et al., 2013). Professional agency contains a dynamic interplay between different narratives, such as enthusiasm and uncertainty (Heikkilä et al., 2020). Teachers can be effective influencers in their social contexts if they are able to cooperate actively (Doring, 2002). In that sense, it is important to support teachers' agency and wider participation in social networks around their workplaces (schools) in teacher education (Payne \& Zeichner, 2017). The concept of agency has an ecological point of view and is connected to the relations among actors, their environments and their actions (Biesta, Priestley, \& Robinson, 2017).

The more focused concept of change agency can be seen in three dimensions: contextual expertise, collaborative expertise and problem-solving expertise (Lukacs, 2011). Change agency is connected to the ability to serve an organization or community as a catalyst of a change process, to recognize dissatisfaction and the need for improvement in the present and to actively promote a change in the organizational culture to achieve the desired future (Manuele, 2015). Teachers' change agency is connected to the idea of formal or informal learning processes according to school agendas (Snoek \& Volman, 2014).

\section{The Need for Change Agency in Education for Sustainable Development}

Combining change agency and sustainable development in education is challenging. Teachers and their work have been seen more as recipients and less as initiators (Lukacs, 2011). Teachers' agency in general is connected to their beliefs and recent policies, rather than a wider understanding of the meanings and purposes of education (Biesta, Priestley, \& Robinson, 2015). There is a need for an epistemological shift (Payne \& Zeichner, 2017) towards more relational agency for teachers (Edwards, 2005). Teachers' relational agency should consist of more collaboration, expand the interpretation of the problem at hand and allow multiple actors to play a more important role in the process (Edwards, 2005). This collaborative approach and active negotiation should be part of teacher education as well. Wider participation from local communities is needed in order to serve an inclusive society more effectively (Zeichner, Payne, \& Brayko, 2015).

There is a need for a whole-school and holistic approach in sustainability education; this promotes the development of school environments where students feel safe, have a sense of belonging and develop the skills needed to participate (Loveless, 2020; Jeronen, Palmberg, \& Yli-Panula, 2017). Jeronen et al. (2017) emphasized the value of inductive teaching methods with student-centered approaches in authentic environments with first-hand experiences. A collaborative approach changes teachers' role to being part of a dialogical and open-ended learning process, through which teachers and students learn and construct their knowledge together (Villanen, 2014; Tolppanen et al., 2017). Different projects, such as Green Flag program for schools, can activate teachers to work more intensively for sustainable development (Elorinne et al., 2020). In teachers' reflections concerning sustainable development and shared processes in learning communities, teachers pointed out awareness, confirmation and collaboration (Villanen, 2014).

Furthermore, there is a need to teach active citizenship to students. Therefore, teachers should teach in a way that develops change agency in children (Akin, Calik, \& 
Engin-Demir, 2017). According to the sustainable development goals (SDGs) target 4.7 "all learners acquire the knowledge and skills needed to promote sustainable development, including, amongst others, through education for sustainable development and sustainable lifestyles, human rights, gender equality, promotion of a culture of peace and non-violence, global citizenship and appreciation of cultural diversity and of culture's contribution to sustainable development" (UN, 2015, p. 17).

Successfully teaching ESD requires a combination of teachers' knowledge, pedagogical practices and attitudes (Esa, 2010). Furthermore, teachers should be able to think critically, work with uncertain information, evaluate values, envision possible futures and have a clear impact on the near future of their working environment and lives (Tolppanen et al., 2017). ESD as a concept is strongly connected to the future (Kollmuss \& Agyeman, 2002; Vesterinen et al., 2016; Maurer \& Bogner, 2019). Student teachers need to understand that complex questions about the well-being of our planet may cause strong negative and positive emotions among students, such as eco-anxiety and hope (Pihkala, 2018), and hopelessness among teachers (Lombardi \& Sinatra, 2013). One of the pedagogical aims should be to give hope to the next generation (Maurer \& Bogner, 2019). However, there is a need for emotional involvement as an affective relationship engages one in pro-environmental behavior (Kollmuss \& Agyeman, 2002).

According to Hofman-Bergholm (2018), higher education in Finland cannot guarantee that student teachers are sufficiently prepared to teach sustainability due to organizational problems. She also highlights that this is a worldwide problem. There are many challenges: the intricate nature of sustainability (Wolff et al., 2017), a lack of time (Borg et al., 2014; Uitto \& Saloranta, 2017), a lack of expertise and the issue of separate academic disciplines within teacher education (Christie et al., 2013; Wolff et al., 2017). HofmanBergholm (2018) argued that ESD had moved from the content of education towards the importance of the process. In other words, education should be pupil-centered to help them develop the skills necessary to act in a changing society.

\section{The Aim and Context of the Study and Research Questions}

The aim of this study is to analyze student teachers' views on their agency regarding sustainable development. The context of this study was a curricular course in teacher education called "Education for a Sustainable Future". This course aimed to enable students to recognize their professional and educational role as participants in society and as educators for a sustainable future. The sustainability content was planned according to UNESCO (2014) and AGENDA 2030 (UN, 2015). The course was provided for the very first time as part of teacher pedagogic studies. All students took part in this course during the final phase of studying. The attendees were students aiming to become primary school teachers, subject teachers, SEN teachers and guidance and counselling personnel.

The idea of using this student material as data emerged during the evaluation process after the course. Originally the aim was to give students a task before the start of the course to orientate them and to give the course teachers more information about the students' baseline to develop their teaching accordingly. The task required students to answer an open-ended question using e-form. They were asked to read descriptions of this specific course and were then asked the following question: "How do you understand the goals of this course in terms of your professionality as a teacher, school culture and society?" 
Based on the answers to this open-ended task, we ask:

1) What kind of variation is there in terms of student teachers' conceptions of change agency?

2) What aspects do student teachers name as their conscious intentions regarding sustainable development?

\section{Methodology}

\section{Participants and Data Collection}

A total of 180 student teachers took part in this study in 2018-2019. Most of the students were at the Bachelor's degree level, studying to become primary school teachers and subject teachers. Ethical aspects were taken into account and participants' anonymity was respected throughout the research process (Finnish National Board on Research Integrity TENK, 2019). We asked all students individually after the course for their permission to use their tasks as research data. Participation was voluntary and 116 students gave us consent to use their tasks.

The nature of the task was such that some students gave short and less informative answers, while other students deeply described their ideas. The range was wide. The shortest answer consisted of 39 words and the longest was 1602 words. However, even the short answers contained some very valuable perspectives.

At the time of data collection, sustainable development was described specifically as part of the new national core curriculum for compulsory education, which was the working environment of most of the participants.

\section{Analysis}

The analysis was based on the phenomenographical approach. The focus was students' conceptions and especially "the structure and essential meaning of the different ways of experiencing the phenomenon" (Marton \& Booth, 1997, p. 114) to reveal the variations in critical aspects captured in qualitatively different descriptions of awareness (Marton \& Booth, 1997). The practical analysis first followed the procedure of content analysis (Elo et al., 2014) and based on this classification it was possible to contribute to the question about the variation of critical aspects. The qualitative analysis was carried out by two researchers and interpretations were cross-checked during the process. The NVivo program was used as a tool. The coding was done by hand because of the nature of the Finnish language.

The frame of the analysis was constructed based on the body of literature introduced above. In the classification process most answers were relatively coherent, but some texts described several, partly controversial conceptions in one answer. In cases where one answer contained several conceptions, the classification was made using the most emphasized level.

Reliability and validity were established through the use of true citations from the original statements in different categories. 


\section{Results}

\section{Student Teachers' Descriptions of Change Agency}

Student teachers' conceptions about change agency were framed in five categories: perpetuating, reactive, aware, proactive and intentional (see Table 1). This classification aims to describe qualitative differences between conceptions of change agency.

\section{Table 1}

Student Teachers' Conceptions About Change Agency

\begin{tabular}{|c|c|c|}
\hline Description & Quotations & $\begin{array}{l}\text { Number of } \\
\text { answers on } \\
\text { this level }\end{array}$ \\
\hline $\begin{array}{l}\text { Perpetuating } \\
\text { No recognized need for } \\
\text { change, status quo }\end{array}$ & $\begin{array}{l}\text { "It is good to remember that teachers are role models } \\
\text { at all levels of the education system". } \\
\text { "Every teacher and student is part of society, and } \\
\text { society both gives possibilities and makes barriers". }\end{array}$ & 14 \\
\hline $\begin{array}{l}\text { Reactive } \\
\text { School has to react to } \\
\text { changes out-of-school }\end{array}$ & $\begin{array}{l}\text { "The teacher has to be prepared to receive changes } \\
\text { in society". } \\
\text { "It is important to adapt to a changing school } \\
\text { environment and culture". }\end{array}$ & 26 \\
\hline $\begin{array}{l}\text { Aware } \\
\text { Recognized and targeted } \\
\text { collective and personal } \\
\text { needs and aims to change, } \\
\text { no methods }\end{array}$ & $\begin{array}{l}\text { "...encourage wide collaboration among teachers to } \\
\text { create guidelines for sustainable development in the } \\
\text { educational world". } \\
\text { "I need to take into account participation and } \\
\text { continuity in my teacher work and understand the } \\
\text { meaning of them". }\end{array}$ & 32 \\
\hline $\begin{array}{l}\text { Proactive } \\
\text { Teacher actively works to } \\
\text { enhance values connected } \\
\text { to aims and creates ideas } \\
\text { or methods for teaching } \\
\text { and what to do in every- } \\
\text { day life }\end{array}$ & $\begin{array}{l}\text { "As a teacher I should raise future generations to take } \\
\text { care of the planet, both nature and humans... for } \\
\text { example, discussing recycling and studying it is a part } \\
\text { of this bigger picture". }\end{array}$ & 29 \\
\hline $\begin{array}{l}\text { Intentional } \\
\text { Aims and methods how } \\
\text { to teach not only sustain- } \\
\text { ability, but furthermore } \\
\text { change agency }\end{array}$ & $\begin{array}{l}\text { "To grow up to be active means to be capable of } \\
\text { critical thinking and being aware of one's possibilities } \\
\text { to make decisions. A teacher can affect students' } \\
\text { thinking, but should support the development of } \\
\text { students' own thinking, so they can in future affect } \\
\text { their own living environments". }\end{array}$ & 15 \\
\hline
\end{tabular}

Perpetuating descriptions were non-personified and distant. There was usually no mention of the writer's own point of view, but instead there were common, general utterances. There were no descriptions of any kind of change. Education maintained the status quo, with teachers and schools delivering, maintaining and holding on to traditions. Where the writer as a person was present in the text, it was in direct connection to the curricular aims of this course.

Reactive descriptions observed changes in society. Changes were general and partly named (such as diversity of cultures and the role of ICT) and those changes caused 
schools and teachers to learn new things and adjust to new phenomena and situations. Society was changing and the role of the educational system and teachers was to adapt passively. Teachers in descriptions are prepared to follow new instructions, and all intentions and aims came from outside. There was no description connected to initiative; rather, there was mention of how society or documents tell us what to change.

Descriptions of awareness were written from a personal perspective ("I", "We") or a professional one ("teacher" or more specifically "SEN teacher" or "teacher of history"). The awareness is based on a professional perspective and named and targeted as initiative; it was described as part of teachers' duties to know what was happening in the world (they were responsible for being aware). However, it was all about knowing, understanding and being conscious - there was no mention of action.

In proactive descriptions there was explicit mention of teachers' activities and responsibilities. In these texts, teachers and schools contribute to sustainability personally or collectively. The teacher is an active member of society, makes personal choices in his/ her own life and knows how important it is to teach children to take sustainability into account.

In the group of intentional descriptions there are explicit descriptions of how teachers can contribute in the school environment and teach children how to create change through their own actions. In other words, these texts tell us not only about sustainability, but also about how to teach children to recognize their agency to make changes.

\section{The Named Aspects as Student Teachers' Conscious Intentions Regarding Sustainable Development}

Most of the student teachers (75) wrote about social dimensions of sustainable development, such as social responsibility, justice, equal opportunities and well-being. Student teachers wrote that the role of teachers, students and school leaders was very important in society. In particular, teachers can influence the socioemotional development of students in school settings. The teachers themselves are the starting point.

"The role of the teacher is to encourage students to participate in decisionmaking and discussion in society”.

"It is possible to build a better school culture, e.g., openness, empowerment, equality and non-discrimination, and a good team spirit among all school members".

Social sustainability education could benefit the local and global society, and provides opportunities for improving learner decision-making and appreciation for social justice and empowerment.

"The school is a part of society. Society is not equal; there are hierarchies between different classes and groups. Some of the values that prevail in our society are very hard values, only emphasising money and success. It is good that the school continues to pass on values and strives to teach students equality".

"Our society is made up of a population which lives under the influence of a particular cultural environment. We get influences from outside our country, but on the other hand we specialise in areas where we have good conditions and opportunities to operate globally". 
For example, becoming more aware of one's own values (31 mentions) can support ESD.

"Education always involves passing on one's own values in one way or another.

It is good to become aware of your own values".

Culture is a driver of sustainable development. Integrating the principles of one's own culture as well as cultural diversity encourages citizens to participate. Cultural sustainability includes the issues surrounding the diversity of staff and students. Participation offers various opportunities to exercise their democratic rights to participate in society, make decisions and act to promote justice, equality and well-being for all. Pedagogical changes from a teaching-based culture to a student-centered learning environment can promote sustainable development. Active participation (101 mentions), critical thinking as well as information and communication technology skills (98 mentions) were the preferred teaching methods to promote the social dimension of sustainable development. Students and society are demanding new knowledge and skills to adapt to the changes that are rapidly occurring on a global, national or local scale.

"Today's students are the decision-makers of the future. The school should provide the widest possible range of critical thinking tools for students".

Teachers can promote social skills through their own interpersonal interactions, creating a positive atmosphere in the classroom. Social sustainability is respect for people, quality of life and democracy, and the ability to work in teams. Social sustainability includes cultural sustainability and corporate sustainability.

"The prevalence of ICT affects school culture and its advantages (the extent of social networks) and disadvantages (cyber bullying) need to be considered from a sustainable development perspective. School well-being is one important aspect of a sustainable future”.

"When the school culture emphasises agency and enables inclusion, it can have a very strong effect, for example in preventing exclusion”.

Few of the student teachers (17) wrote about environmental sustainability. Student teachers wrote that responsible consumption and production were possibilities to prevent environmental degradation. However, there was no mention of biodiversity or climate change. Public and private decisions should be guided by careful evaluation to avoid serious or irreversible damage to the environment. In the school context it is possible to teach decision-making processes.

"Education promotes ecological thinking. Then humans can live in harmony with nature”.

"The food which is thrown in the trash is wrong. New equipment will save energy”.

“...we must pay attention to our environments and consumption habits".

Some of the student teachers wrote about economic dimensions of SD. Governments can promote equal opportunities through providing universal access to education. A reduction in social capital has a negative impact on economic growth and education. Increased economic capital, for example, better resources in education or health care, promotes SD. 
"...I must understand that students come from different families. In the same classroom there can be households with different socioeconomic circumstances."

Economic sustainability includes consideration of short- and long-term costs that are not only financial.

"...Changes in education (financial crisis in education) ..."

However, many student teachers (48) did not name any aspect of sustainable development and five student teachers named all three dimensions of sustainable development but did not specify them in more detail:

"The school should be built on the principles of a sustainable future and set an example for all those involved in the school culture".

"Sustainable development is built in ecologically, socially and economically different ways”.

Figure 1 shows student teachers' perceptions of sustainable development.

\section{Figure 1}

Student Teachers' Perceptions of Sustainable Development

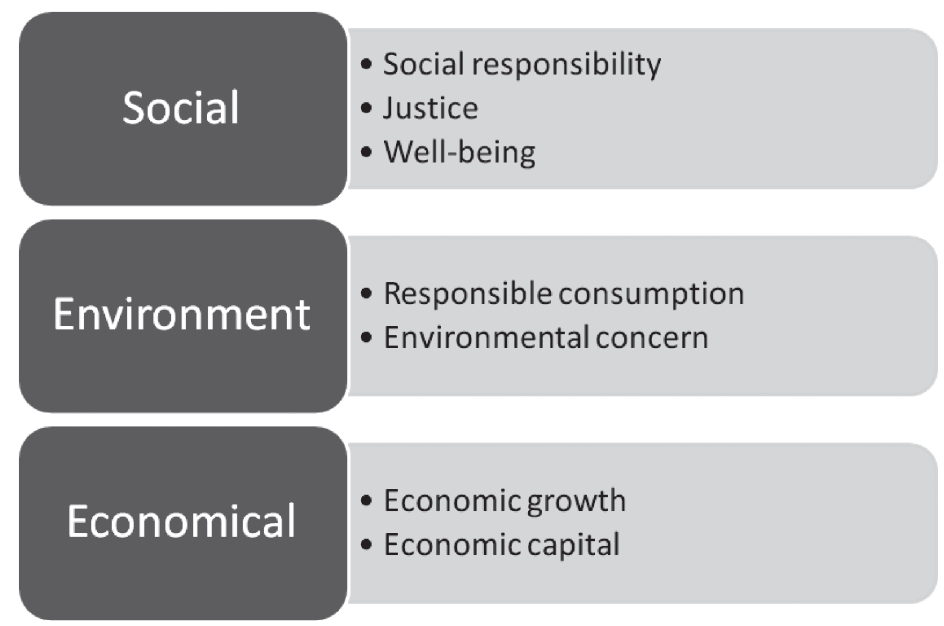

\section{Discussion and Conclusion}

If we understand the ecological and interactional nature of agency (Biesta et al., 2017), we can report the students' side of the process. It is meaningful to understand how students are positioning themselves as they start the initial phase of their professionality. This research provides one structure with which to discuss sustainability and change agency in teacher education.

The findings of this research confirmed previous studies showing that sustainable development issues were complex (e.g., Jeronen et al., 2017). Results confirmed that student teachers' perceptions of sustainable development included all three sustainable development dimensions. The results showed that student teachers generally emphasized 
the social dimension, followed by the economic and environmental dimensions. Political aspects were mainly part of the economic dimension. In this study, student teachers perceived that EDS promoted social and cultural values such as solidarity, equality, democracy and social justice. Health aspects were part of the social dimension. This was not in line with previous studies which highlighted that student teachers mostly wrote about environmental dimensions of sustainable development (Bengtsson et al., 2018).

Student teachers in this study had a sociocultural-focused view of sustainability. The social dimension and especially participation in society were key concepts of democratically oriented ESD. However, ESD also needs other dimensions of sustainable development. During teacher education, it is possible to encourage more pre-service teachers from different disciplines to discuss agency and sustainable development. On the other hand, following the study of Uitto and Saloranta (2017), this can be understood that teachers had different strengths in their competence to teach different sustainability themes. The university curriculum also needs pedagogy which highlights the role of participation in society and teachers' possibilities to teach critical thinking and problemsolving strategies. Wolff et al. (2017) maintain that because of the interdisciplinary nature of sustainability and the fact that universities are autonomous, the implementation of sustainability needs to be seen important not only at the course level, but also in strategies and curricula.

Some limitations of the current study need to be taken into account. The data were analyzed in the context of particular settings and demands, and did not represent any absolute truths about student teachers' perceptions. However, the results were similar to those of previous studies in Finland and all over Europe, which indicated that the sustainable development possessed by student teachers was general in nature. A limitation of the study was the nature of the data. We used a written, voluntary orientation task; not all student teachers engaged deeply in this kind of task. Furthermore, a relatively high number of social dimensions of sustainable development included in the curriculum could be connected to the content of this particular course. However, the task setting was the same for all and there were remarkable qualitative differences in the descriptions. According to the phenomenographical approach, we are aware that we dealt with partly contradictory conceptions. Thus, we acknowledge that there were descriptions at various levels of engagement and understanding of sustainable development and teachers' change agency. Based on our results, we claim that there is a need to discuss teachers' active role in society more explicitly. Especially in Finnish society, where teachers have significant autonomy, we should ask whether all teachers are willing and able to use this autonomy to enhance sustainable development. The results of this study cannot be generalized; however, they may be utilized in planning and implementing student teachers' further education.

\section{References}

Akin, S., Calik, B., \& Engin-Demir, C. (2017). Students as change agents in the community: Developing active citizenship at schools. Educational Sciences: Theory \& Practice, 17, 809-834. http://dx.doi.org/10.12738/estp.2017.3.0176

Anderson, A. (2012). Climate change education for mitigation and adaptation. Journal of Education for Sustainable Development, 6(2), 191-206. https://doi.org/10.1177\% 2F0973408212475199 
Bengtsson, M., Alfredsson, E., Cohen, M., Lorek, S., \& Scroeder, P. (2018). Transforming systems of consumption and production for achieving the sustainable development goals: Moving beyond efficiency. Sustainability Science, 13, 1533-1547. https.//doi.org/10.1007/s11625-018-0582-1

Bennett, S., Jessani, N., Glandon, D., Qui, M., Scott, K., Meghani, A., El-Jardali, F., Maceira, D., Javadi, D., \& Ghaffar, A. (2020). Understanding the implications of the Sustainable Development Goals for health policy and systems research: Results of a research priority settings exercise. Globalization and Health, 16(5). https://doi.org/10.1186/s12992-019-0534-2

Biesta, G., Priestely, M., \& Robinson, S. (2015). The role of beliefs in teacher agency. Teachers and Teaching: Theory and Practice, 21(6), 624-640. https://doi.org/ 10.1080/13540602.2015.1044325

Biesta, G., Priestely, M., \& Robinson, S. (2017). Talking about education: Exploring the significance of teachers talk for teacher agency. Journal of Curriculum Studies, 49(1), 38-54. https://doi.org/10.1080/00220272.2016.1205143

Borg, C., Gericke, N., Höglund, H. O., \& Bergman, E. (2014). Subject-and experiencebound differences in teachers' conceptual understanding of sustainable development. Environmental Education Research, 20(4), 526-551. https://doi.org/10.1080/ 13504622.2013.833584

Brandisauskiene, A., Cesnaviciene, J., Miciuliene, R., \& Kaminskiene, L. (2020). What factors matter for sustainable professional development of teachers? Analysis from four countries. Journal of Teacher Education for Sustainability, 22(2), 153-170. doi: 10.2478/jtes-2020-0022

Chinedu, C. C., Wan-Mohamed, W. A., \& Ogbonnia, A. A. (2018). A systematic review on Education for Sustainable Development: Enhancing Tve teacher training programme. Journal of Technical Education and Training, 10(1), 109-125. https://publisher.uthm.edu.my/ojs/index.php/JTET/article/view/1678

Christie, B. A., Miller, K. K., Cooke, R., \& White, J. G. (2013). Environmental sustainability in higher education: What do academics teach? Environmental Education Research, 19(3), 385-414. https://doi.org/10.1080/13504622.2012.698598

Corcoran, P. B., Walker, K. E., \& Wals, A. E. J. (2004). Case studies, make-your-case studies, and case stories: A critique of case-study methodology in sustainability in higher education. Environmental Education Research, 10(1), 7-21. https://doi.org/ 10.1080/1350462032000173670

Doring, A. (2002). Challenges to the academic role of change agent. Journal of Further and Higher Education, 46(2), 139-148. https://doi.org/10.1080/03098770220129415

Edwards, A. (2005). Relational agency: Learning to be a resourceful practitioner. International Journal of Educational Research, 43, 168-182. https://doi.org/10.1016/ j.ijer.2006.06.010

Edwards, A. (2017). The dialectic of person and practice: How cultural-historical accounts of agency can inform teacher education. In D. J. Clandinin \& J. Husu (Eds.), The SAGE handbook of research on teacher education (pp. 269-285). Sage.

Elo, S., Kääräinen, M., Kanste, O., Pölkki, T., Utriainen, K., \& Kyngäs, H. (2014). Qualitative content analysis: A focus on trustworthiness. SAGE Open, 4(1). https://journals.sagepub.com/doi/pdf/10.1177/2158244014522633 
Elorinne, A.-L., Eronen, L., Pollari, M., Hokkanen, J., Reijonen, H., \& Murphy, J. (2020). Investigating Home Economics teachers' food waste practices and attitude. Journal of Teacher Education for Sustainability, 22(1), 6-20. https://doi.org/ 10.2478/jtes-2020-0002

Emirbayer, M., \& Mische, A. (1998). What is agency? The American Journal of Sociology, 103(4), 962-1023.

Esa, N. (2010). Environmental knowledge, attitude and practices of student teachers. International Research in Geographical and Environmental Education, 19(1), 3950. https://doi.org/10.1080/10382040903545534

Eteläpelto, A., Vähäsantanen, K., Hökkä, P., \& Paloniemi, S. (2013). What is agency? Conceptualizing professional agency at work. Educational Research Review, 10, 45-65. https://doi.org/10.1016/j.edurev.2013.05.001

Fien, J., Maclean, R., \& Park, M. G. (2009). Work, learning and sustainable development: Opportunities and challenges. Springer.

Finnish National Board on Research Integrity TENK. (2019). The ethical principles of research with human participants and ethical review in the human sciences in Finland. https://tenk.fi/sites/default/files/2021-01/Ethical_review_in_human_ sciences_2020.pdf

Giddens, A. (1984). The constitution of society: Outline of the theory of structuration. Polity.

Heikkilä, M., Iiskala, T., \& Mikkilä-Erdmann, M.-M. (2020). Voices of student teachers' professional agency at the intersection of theory and practice. Learning, Culture and Social Interaction, 25, 100405. https://doi.org/10.1016/j.lcsi.2020.100405

Hofman-Bergholm, M. (2018). Changes in thoughts and actions as requirements for a sustainable future: A review of recent research on the Finnish educational system and sustainable development. Journal of Teacher Education for Sustainability, 20(2), 19-33. https://doi.org/10.2478/jtes-2018-0012

Jeronen, E., Palmberg, I., \& Yli-Panula, E. (2017). Teaching methods in biology education and sustainability education including outdoor education for promoting sustainability - A literature review. Education Sciences, 7(1), 1. https://doi.org/10.3390/ educsci7010001

Jimenez, J. D., Lerch, J., \& Bromley, P. (2017). Education for global citizenship and sustainable development in social science textbooks. European Journal of Education, 52(4), 460-476. https://doi.org/10.1111/ejed.12240

Kollmuss, A., \& Agyeman, J. (2002). Mind the gap: Why do people act environmentally and what are the barriers to pro-environmental behavior? Environmental Education Research, 8(3), 239-260. https://doi.org/10.1080/13504620220145401

Laurie, R., Nonoyama-Tarumi, Y., Mckeon, R., \& Hopkins, C. (2016). Contributions of Education for Sustainable Development (ESD) to Quality Education: A synthesis of research. Journal of Education for Sustainable Development, 10(2), 226-242. https://doi.org/10.1177\%2F0973408216661442

Lombardi, D., \& Sinatra, G. M. (2013). Emotions about teaching about human-induced climate change. International Journal of Science Education, 35(1), 167-191. https://doi.org/10.1080/09500693.2012.738372

Loveless, B. (2020). Holistic education: A comprehensive guide, education corner. https://www.educationcorner.com/holistic-education.html 
Lukacs, K. (2011). "For me, change is not a choice": The lived experience of a teacher change agent. American Secondary Education, 44(1), 38-49.

Manuele, F. (2015). Culture change agent: The overarching role of OSH professionals. Professional Safety, 60(12), 38-44.

Marton, F., \& Booth, S. (1997). Learning and awareness. Lawrence Erlbaum.

Maurer, M., \& Bogner, F. X. (2019). How freshmen perceive Environmental Education (EE) and Education for Sustainable Development (ESD). PLoS ONE, 14(1), e0208910. https://doi.org/10.1371/journal.pone.0208910

McKeown, R. (2014). The leading edge of teacher education and EDS. Journal of Education for Sustainable Development, 8(2), 127-131. https://doi.org/10.1177/ 0973408214548366

Murillo-Vargas, G., Gonzales-Campo, C. H., \& Brath, D. I. (2020). Mapping the integration of the sustainable development goals in universities: Is it a field of study? Journal of Teacher Education for Sustainability, 22(2), 7-25. doi: 10.2478/jtes2020-0013

Nousheen, A., Yousuf Zai, S. A., Waseem, M., \& Khan, S. A. (2020). Education for Sustainable Development (ESD): Effects of sustainability education on pre-service teachers' attitude towards Sustainable Development (SD). Journal of Cleaner Production, 250, 119537. https://doi.org/10.1016/j.jclepro.2019.119537

Payne, K., \& Zeichner, K. (2017). Multiple voices and participants in teacher education. In D. J. Clandinin \& J. Husu (Eds.), The SAGE handbook of research on teacher education (pp. 1101-1116). Sage.

Pihkala, P. (2018). Eco-anxiety, tragedy, and hope: Psychological and spiritual dimensions of climate change. Zygon, 53(2), 545-569. https://doi.org/10.1111/zygo.12407

Quinn, F., Castéra, J., \& Clément, P. (2016). Teachers' conceptions of the environment: Anthropocentrism, non-anthropocentrism, anthropomorphism and the place of nature. Environmental Education Research, 22(6), 893-917. https://doi.org/10.1080/ 13504622.2015.1076767.

Rickinson, M. (2001). Learners and learning in environmental education: A critical review of evidence. Environmental Education Research, 7(3), 207-320. https://doi.org/10.1080/13504620120065230

Rittel, H. W., \& Webber, M. M. (1973). Dilemmas in a general theory of planning. Policy Science, 4, 155-169.

Snoek, M., \& Volman, M. (2014). The impact of the organizational transfer climate on the use of teacher leadership competences developed in a post initial Master's program. Teaching and Teacher Education, 37, 91-100.

Sunthonkanokpong, W., \& Murphy, E. (2019). Quality, equity, inclusion and lifelong learning in pre-service teacher education. Journal of Teacher Education for Sustainability, 21(2), 91-104. https://doi.org/10.2478/jtes-2019-0019

Tolppanen, S., Aarnio-Linnanvuori, E., Cantell, H., \& Lehtonen, A. (2017). Pirullisen ongelman äärellä - Kokonaisvaltaisen ilmastokasvatuksen malli [Dealing with a wicked problem - A model for holistic climate change education]. Kasvatus, 48(5), 456-468. http://hdl.handle.net/10138/309462

Tolppanen, S., \& Aksela, M. (2018). Identifying and addressing students' questions on climate change. The Journal of Environmental Education, 49(5), 375-389. https://doi.org/10.1080/00958964.2017.1417816 
Tomas, L., Girgenti, S., \& Jackson, C. (2017). Pre-service teachers' attitudes toward education for sustainability and its relevance to their learning: Implications for pedagogical practice. Environmental Education Research, 23(3), 324-347. https://doi.org/10.1080/13504622.2015.1109065

Torbjörnsson, T., \& Molin, L. (2015). In school we have not time for the future: Voices of Swedish upper secondary school students about solidarity and the future. International Research in Geographical and Environmental Education, 24(4), 338-354. http://dx.doi.org/10.1080/10382046.2015.1086105

Uitto, A., \& Saloranta, S. (2017). Subject teachers as educators for sustainability: A survey study. Education Sciences, 7, 1-19. https://doi.org/10.3390/educsci7010008

UNESCO. (2014). Shaping the future we want: UN Decade of Education for Sustainable Development; final report. https://unesdoc.unesco.org/ark:/48223/pf0000230171

UNESCO. (2016). Education for people and planet: Creating sustainable futures for all. Global education monitoring report. https://unesdoc.unesco.org/ark:/48223/ pf0000245752

UNESCO. (2018). Progress on Education for Sustainable Development and Global Citizenship Education. https://unesdoc.unesco.org/ark:/48223/pf0000266176

United Nations (UN). (2015). Transforming our world: The 2030 Agenda for Sustainable Development. https:/www.un.org/ga/search/view_doc.asp?symbol=A/RES/70/ $1 \&$ Lang=E

Vesterinen, V.-M., Tolppanen, S., \& Aksela, M. (2016). Toward citizenship science education: What students do to make the world a better place? International Journal of Science Education, 38(1), 30-50. https://doi.org/10.1080/09500693.2015.1125035

Villanen, H. (2014). Teachers' reflections on an education for sustainable development project. International Research in Geographical and Environmental Education, 23(2), 179-191. https://doi.org/10.1080/10382046.2014.908526

Waltner, E. M., Rieß, W., \& Brock, A. (2018). Development of an ESD indicator for teacher training and the national monitoring for ESD implementation in Germany. Journal of Sustainability, 10, 2508. https://doi.org/10.3390/su10072508

Wanchana, Y., Inprom, P., Rawang, W., \& Ayudhua, A. J. N. (2020). Environmental education competency: Enhancing the work of teachers. Journal of Teacher Education for Sustainability, 22(2), 140-152. doi: 10.2478/jtes-2020-0021

WHO. (2016). World health statistics 2016: Monitoring health for the SDGs sustainable development goals. WHO Library Cataloguing Data.

Wolff, L.-A., Sjöblom, P., Hofman, M., \& Palmberg, I. (2017). High performance education fails in sustainability? - A reflection on Finnish primary teacher education. Education Sciences, 7(1), 32. https://doi.org/10.3390/educsci7010032

Zeichner, K., Payne, K. A., \& Brayko, K. (2015) Democratizing teacher education. Journal of Teacher Education, 66(2), 122-135. https://doi.org/10.1177/ 0022487114560908

Correspondence concerning this article should be addressed to Sirpa Kärkkäinen, Senior Lecturer, School of Educational Science and Teacher Education, Philosophical Faculty, University of Eastern Finland, P.O. Box 111, Joensuu, Finland. Email: sirpa.a.karkkainen@uef.fi 